\title{
Pressing Problems Related to Development of Pension Schemes in Ukraine and Kazakhstan
}

\author{
Dr. Nataliya Rad (Donetsk National University of Economics and Trade, Ukraine)
}

\begin{abstract}
The article deals with some of the aspects related to development of the present-day conception of pension schemes in Ukraine and Kazakhstan in the context of solving social problems. Demographic and economic conditions for functioning of pension mechanisms of the countries under consideration are analyzed. Comparison of their parameters shows the existence of conceptual characteristics and similar features. Approaches to formation of insurance fees as the background for pension schemes financial balance have been analyzed. Attention is paid to the dependence of financial stability of pension schemes on the level of shadowing of employment relations and wages. Outstanding characteristics for formation of pension assets of insured persons are described. Mutual problems for development of basic pension security are defined. We focus at the insufficient level of development of the non-state pension provision in comparison with the present-day public needs. In the course of our investigations we used the whole complex of general scientific and economicstatistical methods: tabulation procedure, data processing and comparison study. Speculative generalizations and conclusions are made based on the abstract-logical method. We make our proposals to improve the conception of the present-day pension scheme (system) and environment for its functioning for the purposes of further social and economic national development.
\end{abstract}

JEL codes: G23, G28, H21

\section{Introduction}

Socialization is one of the outstanding features of today world development. In this context the urgency of problems related to raising of living standards becomes vital. Special attention in modern conditions is required by the problems of providing moneyed assistance for socially unprotected categories of population to which senior citizens are referred. The status of social welfare state secured in the Constitutions of Ukraine and Kazakhstan means the necessity for forming higher social standards and corresponds with Eurointegration priorities for development of our country (Verkhovna Rada of Ukraine, 1996; The Republican referendum, 1995). At the same time implementation of the problems related to increasing the level of social protection requires considerable financial resources. They can be formed from different sources: at the expense of the nation, partners of business activity and subjects. Functioning of the mixed alternatives of moneyed assistance gives the nation capabilities of selecting the concept of pension system development that meets the level, features and needs of social and economic development.

A key role in formation of the conceptual elements of pension system is plaid by amount of compulsory payments (to secure the rights for pension payments) by participants of respective pension system. We know that overrunning fiscal load hurts ability of economy to compete. That is why the primal problem which academicians and practitioners of Ukraine and Kazakhstan are trying to solve today is search for general (universal) model of pension system, which in addition to improvement of social protection of subjects could contribute also to efficient economic development of the nation. Theoretically this is provided in the three-pillar pension system (Ukrainian version) that includes joint system of mandatory pension insurance and defined contribution pension scheme of mandatory state pension insurance (Verkhovna Rada of Ukraine, 2003a). The Kazakhstan's pension system is also aimed at differentiation of sources of pension payments (in the frameworks of two pillars).

It should be emphasized that modern retirement insurance in the countries under consideration had its origins in the Soviet Union social security system. Recent development of pension systems is taking place in conditions of negative demographic tendencies, aggravation of crisis phenomena in economy and global financial disproportions. All this predetermines necessity of studying pension schemes and framing conceptual lines to overcome the problems. Parnyuk V., Boreiko V., Poluyanov V., Melnichuk V. and many others gave a lot of their attention to research into the nature, essence and features of pension systems. However, pension systems in Ukraine and Kazakhstan continue to be developed. This process runs in conditions of unstable environment of economy and society being transformed. That is why it requires successive analysis, estimation and correction. All stated above argues the relevance of our investigation.

Thus, the object of our paper is analysis of some aspects of pension system functioning in Ukraine in conditions of application of unified social tax and in comparison with the relative elements of the Kazakhstan's pension system; identification of problems and working out guidelines for improvement of these parameters in the context of solving problems of social and economic development. 
Our investigation is based on dialectic and system approaches. In the course of our investigation we employed a group of general scientific and statistical techniques: statistical analysis and processing of data, pooling of data, comparative analysis and others. Abstract and logic method was used for making theoretical generalizations.

\section{Problem description}

For the purposes of our investigation we should keep in mind that pension system reforming is part of the transformation processes that take place in the state. Effectively functioning real sector of economy, sufficiently enough number of workplaces for embracing citizens of economically active age and high standard of wages (earnings) can be considered as the main conditions for successfully acting pension system. These factors are indeed the basis for correct planning of pension assets of the main participants of pension system for long-term perspective. They also specify the level of financial stability of pension system itself.

It is appropriate to note that the main generalizing indicator of economic growth - gross domestic product (GDP) shows the level of economic potential of the state that can be used for development of its social services. GDD per capita in Kazakhstan exceeds that in Ukraine by a factor of 1.8. Analysis of GDP and its components of the countries under consideration is given in Table 1.

\begin{tabular}{|l|c|c|}
\hline \multicolumn{1}{|c|}{ Parameters/Country } & Ukraine & Kazakhstan \\
\hline GDP (official exchange rate), (2011 est.), \$ & 162,9 billion & 180,1 billion \\
\hline GDP (composition by sector), (2011 est.) \% & 100,0 & 100,0 \\
\hline - agriculture, (2011 est.) \% & 9,3 & 5,2 \\
\hline - industry, (2011 est.) \% $\%$ & 34,7 & 37,9 \\
\hline - services, (2011 est.) \% & 56,1 & 56,9 \\
\hline GDP (real growth rate), (2011 est.) \% & 5,2 & 7,5 \\
\hline GDP (per capita, PPP), (2011 est.), \$ & 7200,0 & 13000,0 \\
\hline
\end{tabular}

Table 1. Main Characteristics of GDP of Ukraine and Kazakhstan in 2011. Sources: Central Intelligence Agency, 2011a; State Statistic Committee of Ukraine, 2011 a.

In spite of available differences, success of any type of pension scheme (system) depends primarily on the coverage by it of potential participants. Degree of fulfillment of this condition affects first and foremost amounts of pension taxes. This correlation can be seen both within each specific period and in the intergenerational cutout. At the same time, one of the main conditions that specify peculiarities of formation of potential community of participants of each of pension schemes is demographic situation, the main parameters of which are shown in Table 2.

\begin{tabular}{|l|c|c|}
\hline \multicolumn{1}{|c|}{ Parameters/ Country } & Ukraine & Kazakhstan \\
\hline Population (million) & 45,1 & 15,5 \\
\hline $\begin{array}{l}\text { Age Distributions } \\
\text { (\% of population) }\end{array}$ & 100,0 & 100,0 \\
\hline 0-14 years & 13,7 & 21,6 \\
\hline 15-64 years & 70,8 & 71,0 \\
\hline$>$ 65 years & 15,5 & 7,4 \\
\hline Median age (total), years & 39,9 & 30,2 \\
\hline Median age (male), years & 36,7 & 28,7 \\
\hline Median age (female), years & 43,1 & 31,9 \\
\hline Population growth rate (2011 est.), \% & $-0,622$ & 0,4 \\
\hline Life expectancy at birth (total population), years & 68,58 & 68,51 \\
\hline Life expectancy at birth (male), years & 62,79 & 63,24 \\
\hline Life expectancy at birth (female), years & 74,75 & 74,08 \\
\hline Expectancy population at 2050, million & 39,3 & 18,7 \\
\hline Laborforce (million) & $22,02(2010$ est.) & $8,61(2010$ est.) \\
\hline Laborforce by occupation, (\%): & 100,0 & 100,0 \\
\hline - agriculture, \% & 15,8 & 28,2 \\
\hline - industry, \% & 18,5 & 18,2 \\
\hline - services, \% & $65,7(2010$ est.) & $53,6(2010$ est.) \\
\hline Unemployment (\% of workforce) & 7,9 & 5,4 \\
\hline
\end{tabular}

Table 2. Demography and labor markets parameters of Ukraine and Kazakhstan in 2011. Sources: Central Intelligence Agency, 2011b; State Statistic Committee of Ukraine, 2011 b.

Analysis of demographic indicators allows us to see the advantages and system-based problems related to development of the countries in the context of the existing structure of age-group populations. These factors are 
indicators for the formation of conceptual approaches to the construction of pension scheme elements. We can consider as the main estimate demographic indicators (for the purposes of pension scheme development) the ratio of persons, who attained pension age in the general population composition; the ratio of persons, who attained pension age to citizens of economically active age (dependency ratio); the ratio of pensioners to the number of the employed; the ratio of persons acquired age ( $>65$ years) to the number of children under 5 years of age, and others. The data given in Table 2 shows that demographic situation in Kazakhstan is characterized by younger generation-indicators. For this speaks the median age of the population: the data is $9.7 \%$ less in general, $8.0 \%$ less for male and $11.2 \%$ less for female than those similar indicators for Ukraine. At practically equal expected lifetime of citizens (at birth) the population of advanced age in the general population composition in Kazakhstan is by $9.1 \%$ less than in Ukraine. This argues the more optimal dependency ratio of senior citizens for the category of economically active population in Kazakhstan (10.4\%) in comparison with Ukraine (21.9\%). The indicator that characterizes the ratio of senior citizens to the category of young people (who do not attained working age) in Kazakhstan (34.4\%) can also be considered as the more optimal in comparison with the similar in Ukraine $(13.1 \%)$. However, in this context it is important to note that in the research environment there have been formed definite evaluating stereotypes which consider domination of population of young age in the general population composition as positive factors. One of the peculiarities of the present-day pension system, to our opinion, is the necessity of considering its characteristics in the longer term change. When we consider the ratio of junior and senior population in relation to economically active age-population, we can see that the more optimal ratio has been formed in Kazakhstan (7.4\% and 21.6\%) than the similar ratio in Ukraine $15.5 \%$ and $13.7 \%$ ). However, in the long-term measurement, when replacement of generations take place, indicators in Kazakhstan will have less positive characteristics that those in Ukraine (changes in the category of persons of economically active age were not taken into account for this case study). Accordingly, the most optimal will be equal ratio of replaceable groups of employable population and incapacitated persons (junior and senior in comparison with population of economically active age) in the long-term perspective. This is because sizable fluctuation of demographic determinants has destructive influence on economic and financial sectors of the state. Looking forward we can assume ever more increasing influence of this factor on pension scheme development. This argues the necessity of working out the strategy for demographic development for long-run period for the purposes of pension system transformation. Describing labour sector we can see that at practically equal ratio of economically active population the percentage of labour force in Kazakhstan $(77.2 \%)$ exceeds similar indicator in Ukraine $(69.02 \%)$. One of the explanations of this is the possibility of losing economic activity (capacity for work) at a more early age than that foreseen by generally accepted limits when working in detrimental to health industries. It is important to note the existence of one of the negative factors in employment sector for the countries under consideration: it is unemployment the level of which in Ukraine is $2.5 \%$ higher than that in Kazakhstan. Taken as a whole, this affects development of pension system and requires to be controlled at the state level. There are good reasons to point out that formation of pension system parameters is governed to a considerable degree by macroeconomic conditions shown in Table 3 .

\begin{tabular}{|l|c|c|}
\hline \multicolumn{1}{|c|}{ Parameters/Country } & Ukraine & Kazakhstan \\
\hline Investment (gross fixed), \% of GDP (2011 est.) & 19,0 & 18,3 \\
\hline Inflation rate, \% (2011 est.) & 9,0 & 7,4 \\
\hline Taxes and other revenues, \% of GDP (2011 est.) & 26,9 & 21,5 \\
\hline Budget surplus (+) or deficit (-), (\% of GDP), (2011 est.) & $-4,0$ & $-2,3$ \\
\hline Public debt (\% of GDP, (2011 est.) & 44,8 & 16,0 \\
\hline Stock of narrow money (2011 est.), \$ & 36,41 billion & 22,65 billion \\
\hline Stock of broad money (2011 est.), \$ & 74,96 billion & 77,23 billion \\
\hline
\end{tabular}

Table 3. Basic macroeconomic indicators of Ukraine and Kazakhstan in 2011. Sources: Central Intelligence Agency, 2011c; State Statistic Committee of Ukraine, 2011c.

It should be emphasized that existing direct relationship between rate of retirement pension, pensionable service duration and wage level (earnings) and also insurance payments in pension schemes of Ukraine and Kazakhstan enables to control equilibration between pension liabilities and retirement cash flows with the help of insurance payment parameters. There are different conceptual approaches to their formation (see Figure 1). 


\begin{tabular}{|c|c|c|c|}
\hline \multicolumn{4}{|c|}{ Main parameters of insurance contributions formation } \\
\hline$\downarrow$ & $\downarrow$ & $\downarrow$ & $\downarrow$ \\
\hline $\begin{array}{l}\quad \text { Taxation basis } \\
\text { Payroll (income) } \\
\text { Contract provisions } \\
\text { Established in } \\
\text { accordance with } \\
\text { legislation }\end{array}$ & $\begin{array}{l}\quad \quad \begin{array}{c}\text { State of } \\
\text { aggregation }\end{array} \\
\text { Independent } \\
\text { payment (insurance } \\
\text { payment) } \\
\text { Integrated payment } \\
\text { (unified insurance } \\
\text { contribution) } \\
\text { Compensation } \\
\text { payment }\end{array}$ & $\begin{array}{l}\quad \text { Amounts } \\
\text { Amounts added to } \\
\text { payroll (income) } \\
\text { Payroll burdens } \\
\text { (income) } \\
\text { Minimum insurance } \\
\text { contribution } \\
\text { Maximum level } \\
\text { Fixed amount }\end{array}$ & $\begin{array}{l}\quad \text { Payers } \\
\text { Insurees } \\
\text { Indemnified persons } \\
\text { Safety funds } \\
\text { National budget }\end{array}$ \\
\hline
\end{tabular}

Figure 1. Main parameters of insurance contributions formation. Source: the author's definition.

The pay-as-you-go pension scheme traditionally uses the earnings of insured persons as the basis for assessment of insurance payments. One of the main advantages of these economic categories is that being a source for assessment of insurance payments they are also a reflection of its part to be returned in case of loss of earning capacity. This correlation is one of the principal indicators reflecting pension scheme sociality and quality. However, today judgments appear that expand the scope of conceptual approaches towards insurance contributions formation (see Table 4).

\begin{tabular}{|l|l|l|}
\hline \multicolumn{1}{|c|}{ Parameters } & \multicolumn{1}{|c|}{$\begin{array}{c}\text { Methodological approach towards } \\
\text { taxation object formation }\end{array}$} & \multicolumn{1}{|c|}{ Impact on pension scheme } \\
\hline Wages (earnings) & $\begin{array}{l}\text { According to the Act of Ukraine "On } \\
\text { Labour Remuneration" the earnings shall be } \\
\text { not less than minimum and not more than } \\
\text { maximum of insurance payment }\end{array}$ & $\begin{array}{l}\text { Positive: has personified character } \\
\text { and incentive potential of insured } \\
\text { principles } \\
\text { Negative: facilitates shadowing of } \\
\text { earnings }\end{array}$ \\
\hline Wages (earnings) & The whole amount & $\begin{array}{l}\text { Positive: increases potential of } \\
\text { financial security } \\
\text { Negative: facilitates shadowing of } \\
\text { earnings }\end{array}$ \\
\hline Base norm wage fund & $\begin{array}{l}\text { Product of employment size on the } \\
\text { established living wage }\end{array}$ & $\begin{array}{l}\text { Negative: incentive potential of } \\
\text { insured principles is lacking; } \\
\text { contributes to lowering of } \\
\text { financial security }\end{array}$ \\
\hline $\begin{array}{l}\text { Receipts from sale of } \\
\text { products (goods, woks, } \\
\text { services) }\end{array}$ & Unified social tax & $\begin{array}{l}\text { Negative: personified character } \\
\text { and incentive potential of insured } \\
\text { principles are lacking }\end{array}$ \\
\hline
\end{tabular}

Table 4. Conceptual approaches towards insurance contributions formation. Sources: Verkhovna Rada of Ukraine, 2003b; Boreiko, 2006; Parnyuk, 2006.

One of the critical objects for a dispute is qualifying insurance contributions as a category of social, insurance or tax payments (Poluyanov, 2006). Although this payment has similar to tax features and insurance nature, it is social transfer in itself. Therefore its parameters, to our opinion, at any form of compensation shall provide first and foremost sufficient level of future retirement assets. Earnings are developing category. Transformation of economic activity facilitates transfer of sources of earnings formation into financial sector. Tax-free earning of incomes is gaining ground and becomes more popular. These are dividend yield, income from rental, income from securities and many others being often the main and the only means of living. We consider that it makes sense to expand insurance payment taxation for these incomes.

Comparative analysis of pension systems in Ukraine and Kazakhstan shows that they have similar conceptual features and differences lying in the basis of formation of their pension system products shown in Table 5 . 


\begin{tabular}{|c|c|c|}
\hline Type/Parameter/Country & Ukraine & Kazakhstan \\
\hline \multicolumn{3}{|l|}{$\begin{array}{l}\text { The first level: overall coverage, } \\
\text { redistribution }\end{array}$} \\
\hline \multicolumn{3}{|l|}{ State retirement benefits (state pension) } \\
\hline Special (Targeted) & + & + \\
\hline Basic & + & - \\
\hline Minimal & + & + \\
\hline Coverage & All employed Ukraine citizens & All employed Kazakh citizens \\
\hline Second level: mandatory insurance & Notional accounts & Mandatory individual accounts \\
\hline Coverage & All employed Ukraine citizens & $\begin{array}{l}\text { All employed persons residing } \\
\text { in Kazakhstan }\end{array}$ \\
\hline $\begin{array}{l}\text { Third level: voluntary insurance } \\
\text { (private) }\end{array}$ & + & - \\
\hline Social insurance & & $\begin{array}{l}\text { Employed (excluding working } \\
\text { pensioners) and self-employed } \\
\text { persons, including foreign } \\
\text { citizens and persons without } \\
\text { citizenship who work and reside } \\
\text { permanently in Kazakhstan }\end{array}$ \\
\hline Types of pension & Old Age, Disability, Survivors & Old Age, Disability, Survivors \\
\hline \multicolumn{3}{|l|}{ Conditions for granting pension: } \\
\hline \multicolumn{3}{|l|}{$\begin{array}{l}\text { Retirement age (old-age solidarity } \\
\text { pension): }\end{array}$} \\
\hline - male & 60 & 63 \\
\hline - female & 60 & 58 \\
\hline - reduced & Yes & Yes \\
\hline \multicolumn{3}{|l|}{$\begin{array}{l}\text { Period of participation in (old-age } \\
\text { solidarity pension system) }\end{array}$} \\
\hline - male & 35 & 25 \\
\hline - female & 30 & 20 \\
\hline - reduced & $20-25$ & $20-25$ \\
\hline Minimum old-age pension & $\begin{array}{l}\text { Fixed by law (in the national } \\
\text { budget) - } 938 \text { hrn. (est. 2012) }\end{array}$ & $\begin{array}{c}\text { Fixed by law (in the national } \\
\text { budget) }-6,700 \text { tenge (est. 2006) }\end{array}$ \\
\hline $\begin{array}{l}\text { Period of used wages (old-age } \\
\text { solidarity pension system): }\end{array}$ & $\begin{array}{c}\text { For any } 5 \text { years till } 01.07 .2000 \\
\text { and for the whole period } \\
\text { following this data }\end{array}$ & $\begin{array}{c}\text { For } 3 \text { consecutive years after } \\
1995\end{array}$ \\
\hline \multicolumn{3}{|l|}{$\begin{array}{l}\text { Sources of Funds (old-age solidarity } \\
\text { pension system): }\end{array}$} \\
\hline Insured person, $\%$ & $\begin{array}{l}2.0 \%-4.5 \% \text { of earnings } \\
\text { (unified social tax) }\end{array}$ & - \\
\hline $\begin{array}{l}\text { Self-employed person, } \\
\%\end{array}$ & $\begin{array}{l}33.2 \% \text { of earnings (unified } \\
\text { social tax) }\end{array}$ & calculated indicator (social tax) \\
\hline Employer, \% & $\begin{array}{l}33.2 \% \text { of payroll (unified } \\
\text { social tax) }\end{array}$ & $11.0 \%($ social tax $)$ \\
\hline \multicolumn{3}{|l|}{$\begin{array}{l}\text { Sources of Funds (mandatory } \\
\text { individual account) }\end{array}$} \\
\hline Insured person, $\%$ & $2.0 \%-7.0 \%$ of payroll & $10.0 \%$ of monthly earnings \\
\hline Self-employed person, $\%$ & $2.0 \%-7.0 \%$ of payroll & $\begin{array}{l}10.0 \% \text { of monthly income (not } \\
\text { less then } 10 \% \text { of the minimum } \\
\text { wage and not more then } 10.0 \% \\
\text { of } 70 \text { times the minimum wage }\end{array}$ \\
\hline Social insurance, $\%$ & - & $\begin{array}{l}2.0 \%(3.0 \% \text { in } 2007) \text { of the } \\
\text { monthly minimum wage; } \\
18.0 \% \text { of monthly income (is } \\
\text { paid to the state budget) }\end{array}$ \\
\hline
\end{tabular}

Table 5. Comparison of pension system parameters in Ukraine and Kazakhstan. Sources: the author's definition Sources: Pension Fund of Ukraine, 2011; Ministry of Labor and Social Protection of Population of the Republic of Kazakhstan, 2011; SSPTV: Asia and Pacific, 2006. 
Retirement insurance in Ukraine and in Kazakhstan provides for covering insured events related to retirement age, disability and survivors' benefits insurance. It makes sense to note progressive increase in pension payments in Ukraine and in Kazakhstan from 21.6 USD and 29.3 USD in 1995 to 124.7 USD in 2009 respectively (Rudik, 2011; Melnichuk, 2010). The positive feature of both pension schemes is tolerance level of pension secured in legislation. Introduction of unified social tax in Ukraine in 2010 has enabled to combine administration of insurance payments of four insurance funds that control insured events related to pension coverage, temporary loss of capacity to labour, occupational accidents, and unemployment. Combining of payments facilitated to a considerable degree simplification of their administration by insurees. However, these changes had no effect on the concept of their formation. At the same time, national strategy of innovative development requires competitive growth of the economy. Social taxes on retirement insurance are constituent part of costs and therefore their amounts require optimization.

It should be pointed that one of the general features characterizing conditions for functioning of pension schemes under consideration is presence of industries with harmful labor conditions that makes provision for earlier (than on the usual terms) retirement age of workers. In conditions of more unfavorable demographic situation this problem has a negative effect on the development of Ukraine's and Kazakhstan's pension systems and necessitates solution in the frameworks of further pension transformations.

Thus, it seems clear that functioning of all acting forms of retirement insurance in the countries under consideration is accompanied by general problems related to limited abilities of guaranteed permanent appointment through the duration of economically active age, insufficient salary level for participation in retirement saving insurance, institutional insufficiency of financial market and investment instruments, and high level of risks at all stages of formation, capitalization and maintenance of pension assets of insured parties and also conceptual shortcoming of pension system elements (Hinz, at. al, 2005; International Labour Office, 2003). This assumes necessity of creating maximally favorable conditions for development of all forms of pension system.

\section{Conclusions}

Our study has shown that as consisted with the declared by Ukraine and Kazakhstan course for improvement of social standards the level of social security of citizens even though is rising, but is still low in comparison with European countries. The process of three-pillar pension system development takes place in conditions of unfavorable demographic situation, imperfection of financial market and investment environment, deficiency of efficient instruments for capitalization and protection of pension assets against risks. Today under current conditions the potential of Ukraine's and Kazakhstan's pension systems is not being realized in full. A key role in this is played by quality of the mechanism and instruments for income generation of the relative pension funds.

To achieve both greater efficiency and gains in performance of this process we consider that it is necessary:

1. To formulate national strategy for optimization of demography in the long term.

2. To work out conception for expanding taxation (unified social tax) by means of inclusion of passive incomes in taxation base.

3. To optimize parameters of rates of insurance (unified social tax) in order to reduce fiscal load on partners of business activity and to provide financial equilibration of budgets of Pension Funds in long-term perspective.

Implementation of the above measures will enable to activate the process of pension transformations and will contribute to improving standards of social security system for citizens in the context of realization of the national priorities for innovative development.

\section{References}

- Boreiko, 2006. "How to decrease interest deductions to Pension Fund", Economy of Ukraine, 539, p. 30-35.

- Central Intelligence Agency, 2011. The World Factbook, http://www.cia.gov/library/publications/theworld-factbook/

- Hinz, Zviniene and Vilamovska, 2005. The New Pensions in Kazakhstan: Challenges in Making the Transition, http://www.siteresources.worldbank.org/.../Pensions/

- International Labour Office, 2003. Inception report on Targeted Social Assistance Scheme, http://www.ilo.org/public/english/bureau download/Kazakhstan

- Melnichuk, 2010. “Trends in development of Ukraine's pension system”, Finances of Ukraine, 173, p. 66-76.

- $\quad$ Ministry of Labor and Social Protection of Population of the Republic of Kazakhstan, 2011. Social insurance, http://www.enbek.gov.kz/ru 
- Parnyuk, 2006. "On the necessity to change methodological approach to charge dues to Pension and Social Funds", Economy of Ukraine, 533, p. 16-21.

- Pension Fund of Ukraine, 2011. Statistic information, http://www.pfu.gov.ua/pfu/control/uk/publish/category?cat_id=38943,

- Poluyanov, 2006. "On the change of the base to calculate allowances of enterprises to social funds", Economy of Ukraine”, 539, p. 25-29.

- Rudik, 2011. "The influence of demographic factors on the introduction of mandatory accumulative pension insurance in Ukraine”, Finances of Ukraine, 182, p. 31-39.

- SSPTV: Asia and Pacific, 2006. Social Security in Kazakhstan, http://www.ssa.gov/policy/docs/progdesc/ssptw...kazakhstan.pdf

- State Statistic Committee of Ukraine, 2011. Statistic information, http://www.ukrstat.gov.ua

- The Republican referendum, 1995. The Constitution of the Repablic of Kazakhstan, http:// www. Constitution.kz./razdel1/

- Verkhovna Rada of Ukraine, 1996. The Ukrainian Constitution, http:// zakon1.rada.gov.ua/cgibin/laws/

- Verkhovna Rada of Ukraine, 2003. Act of Ukraine dd. 09.07.2003 No 1058. "On Obligatory NationalLevel Retirenment Insurance”, http://www.zakon1.rada.gov.ua/cgi-bin/laws/main.cgi?nreg=105815zakon1.rada.gov.ua 